\title{
Response of Different Sweet Potato (Ipomoea batatas Lam) Cultivars to Different Levels of NPK 15:15:15 in Igbariam, Anambra State, Nigeria
}

\author{
Evans E. Okoli ${ }^{*}$ and M.J. Nworji ${ }^{2}$ \\ ${ }^{1}$ Department of Crop Science and Horticulture, Chukwuemeka Odumegwu Ojukwu \\ University, P.M.B. 6059 Awka, Anambra State, Nigeria. \\ 2Department of Forestry and Wildlife Management, Chukwuemeka Odumegwu Ojukwu \\ University, P.M.B. 6059 Awka, Anambra State, Nigeria. \\ *correspondence: Dr. Evans Ebuka Okoli; ee.okoli@coou.edu.ng
}

\begin{abstract}
A research study on the response of different sweet potato cultivars to different levels of NPK 15:15:15 in Igbariam Anambra State, Nigeria was was conducted between May and July 2018 at the teaching and research farm of the Department of Crop Science And Horticulture, Faculty of Agriculture, Chukwuemeka Odumegwu Ojukwu University (COOU) Igbariam Anambra state.It was a factorial experiment laid out in Randomized Complete Block Design (RCBD) with four replications. Three varieties of Sweet Potato viz; TIS 87/0087, Umuspo 1 and Umuspo 3 were planted. Four fertilizer treatments NPK 15:15:15 at 200kg/ha 300kg/ha $400 \mathrm{~kg} / \mathrm{ha} 0 \mathrm{~kg} / \mathrm{ha}$ were applied four weeks after planting. Data was collected at 2 weeks' interval on growth parameters and yield parameters. Analysis of variance was used to know the significant effect of blocking and treatment on various parameters evaluated and separation of treatment means was done using Fisher's least significant difference. Sweet potato variety Umuspo 1 was found to produce significantly $(\mathrm{P}<0.05)$ large number of leaves and was well established compared to other varieties. Umuspo 3 and Tis87/0087 produced longer vine than Umusopo 1. Generally, increase in fertilizer rate resulted in increase in vegetative growth. TIS87/0087 was best in the overall yield performance when compared to other cultivars. Therefore, NPK 15:15:15 at the rate of $300 \mathrm{~kg} / \mathrm{ha}$ can be recommended for the production of TIS/87/0087 in the study area, further breeding work is also recommended.
\end{abstract}

Keywords: responses; sweet potato; NPK 15:15:15; Igbariam; breeding

\section{INTRODUCTION}

Sweet potato (Ipomea batatas) is herbaceous dicotyledeon widely grown throughout the tropics and temperate region of the world between the latitude $40 \mathrm{~N}$ and of the equator and between the sea level and $2300 \mathrm{~m}$ altitude.

Sweet potato ranks second following Irish potato in the world tuber and root crops production and third after Irish potato and cassava consumption in several parts of tropical Africa, (Lenne, 1991). It is undeniable of the most important food crops due to its high yield and nutritive value; the area of production and the productivity of sweet potato are increasing globally. India is the leading producer (91.1 million tons) of this crop along with China (81.2 million) _ (FAOSTAT, 2010). In sub-Sahara Africa, sweet potato is third most important tuber after Cassava (Manihotesculenta) and yam (DioscoreaSpp). Nigeria is the leading producer of sweet potato with 3.46 million tone (FAO, 2001). Cultivation is being encouraged in Africa where vitamin A deficiency is serious health problem. The importance of this crop cannot be over emphasized as it is among the roots crops that play important roles in parts of tropical Africa.
Okoli and Okoronkwo (2020) revealed that the development of highly nutritious crops will improve the nutritional status of the region and generally the standard of living of farmers in South-eastern Nigeria. It constitutes food for man, animals and other purpose at the rate of 30percent, 63 percent and 7 percent, respectively. Sweet potato can be made into syrup and also serve as raw material for the manufacture of alcohol etc. Sweet potato usually has a higher protein content that varies from 1 to 2.5 percent; Carotenes precursors of vitamin A are often variety and the leaves are rich in protein up to 34 percent crude protein (Tesfayeet al., 2003). In recent times, the production rate of sweet potato has been on decrease despite its numerous economic and nutritional values. The decrease can be attributed primarily to decline in soil nutrients status consequently leads to decline in yield.

Though organic manure could be useful in the production of sweet potato due to its beneficial effect on the soil and crop, but its bulkiness, slow release of nutrients and difficult to handle poses serious challenges especially in commercial production. Though inorganic fertilizer is relatively expensive, its fast release of nutrients and easy 
handling makes it better option especially for commercial production. Furthermore, sweet potato is short duration crop which requires inorganic fertilizer that releases nutrient in the soil for plant uses faster. Therefore, uses of inorganic fertilizer will very likely be more efficient in increasing the yield. The response of different sweet potato varieties (improved and local) to inorganic fertilizer may as well vary. Hence, this study was designed to evaluate the responses of three cultivars of sweet potato to different levels of NPK 15:15:15 fertilizer in Igbariam Anambra State, Nigeria.

\section{Materials and methods}

The field experiment was conducted at the experimental site of Chukwuemeka OdumegwuOjukwu University Anambra state in the Eastern part of Nigeria. The site was planted with sweet potatoes between May and July 2018.Three varieties of sweet potato (Ti587/0087, Umuspo3, Umuspo 1) that are resistant to sweet potato virus disease were planted for the experiment. All varieties were sourced from National Root Crop Research Institute (NCRCI) Umudike, Abia State.

\section{Treatment and experimental design}

The treatment combined following a $4 \times 3$ factorial arrangement fitted into randomized complete block design with 4 replicates. The main plot was 4 fertilizer rates: 15:15:15:200Kg/ha, $300 \mathrm{~kg} / \mathrm{ha}, 0 \mathrm{~kg} / \mathrm{ha}$, and $400 \mathrm{~kg} / \mathrm{ha}$. The varieties of sweet potato used are Tis87/0087, Umuspo 3, Umuspo1.

\section{Land preparation and planting}

The land was prepared using cutlass and hoe. The land was measured into four blocks each $2 \mathrm{~m} \times 1 \mathrm{~m}$, the blocks were divided into 12 plots, the three sweet potato varieties Tis87/0087, Umuspo 3, Umuspo 1 were cut into $20 \mathrm{~cm}$ length. Each vine was planted at spacing $0.5 \mathrm{~m} \times 1 \mathrm{~m}$ to give 6 stands per plot. There is a total of 48 plots. Periodically vines of each treatment's plots were dragged to their respective plots to avoid nutrient flow between plots. Periodically vines of each treatment plots were dragged to their respective plots to avoid nutrient flow between plots.

\section{Pre-planting soil sampling}

Prior to ridging, soil samples of the experimental site were randomly collected using soil auger.

\section{Cultural practices}

Appropriate quantity of fertilizer was measured using a scale and applied manually 4 weeks after planting. The method used was side placement. Regular weeding was carried out when due. No pesticide or herbicide was applied throughout the period of the experiment.

\section{Data collection and statistical analysis}

To know the effect of mineral fertilizer on growth and yield parameters of sweet potato, data were collected on vine length, number of leaves, germination count.

Number of leaves per plant: the number of leaves per plant was obtained by counting the number of leaves of each selected plant within the plot after which their mean was calculated and recorded.

Vine length: this was measured using measuring tape and is the distance from the ground level to the top of the vine.

Yield: Tuber length, weight of marketable and unmarketable tubers.

Yield of marketable and unmarketable tubers: This was measured in kilogram by weighing the root of plants in plots after which the average was calculated and recorded.

\section{Statistical analysis}

The data collected were subjected to Analysis Of Variance (ANOVA) using Gen.Stat Release 10.3 statistical software. The means will be compared using Fisher's least Significance Difference (F-LSD) as described by (Obi, 2002).

\section{RESULTS \\ Growth parameters}

\section{- Number of leaves}

TABLE 1 showed that at 2 and 4 weeks after planting that there was significant difference for variety but there was no interaction between sweet potato varieties and fertilizer rates. At 4 weeks $300 \mathrm{~kg} /$ ha gave the highest number of leaves while $200 \mathrm{~kg} /$ ha gave the least number of leaves.

TABLE 1: Effect of difference rates of NPK 15:15:15 fertilizer on the number of leaves three varieties of sweet potato.

\section{NPK FERTILIZER}

\begin{tabular}{|c|c|c|c|c|c|}
\hline & NPK 0 KG & NPK 200 KG & NPK $300 \mathrm{KG}$ & NPK $400 \mathrm{KG}$ & Mean \\
\hline VARIETY & \multicolumn{5}{|c|}{ NUMBER OF LEAVES 4 WAP } \\
\hline TIS $87 / 0087$ & 11.42 & 10.58 & 13.33 & 13.58 & 12.23 \\
\hline UMUSPO3 & 10.75 & 8.33 & 8.42 & 8.33 & 8.96 \\
\hline UMUSP01 & 15.58 & 16.25 & 20.67 & 18.42 & 17.73 \\
\hline MEAN & 12.58 & 11.72 & 14.14 & 13.14 & \\
\hline
\end{tabular}

\section{VARIETY}

$\begin{array}{ll}\text { TIS 87/0087 } & 22.1 \\ \text { UMUSPO3 } & 33.2 \\ \text { UMUSPO1 } & 35.4 \\ \text { MEAN } & \mathbf{3 1 . 8}\end{array}$

LSD (0.05) for sweet potato variety means LSD (0.05) NPK 15:15:15 Fertilizer means LSD (0.05) for sweet potatoes variety X NPK 15:15:15: Fertilizer means

\section{NUMBER OF LEAVES 6 WAP}

$\begin{array}{llll}26.8 & 31.8 & 35.5 & 28.7 \\ 34.4 & 43.7 & 31.4 & 35.7 \\ 45.2 & 42.4 & 34.2 & 39.6 \\ \mathbf{3 5 . 4} & \mathbf{3 9 . 3} & \mathbf{3 3 . 7} & \end{array}$

$\begin{array}{cc}\text { NOL } 2 \text { WAP } & \text { NOL } 4 \text { WAP } \\ 3.67 & 8.40 \\ \text { N.S } & \text { N.S } \\ \text { N.S } & \text { N.S }\end{array}$


- Vines length

TABLE 2 showed the responses of vine length of three varieties of sweet potato to different levels of NPK 15:15:15.

There was no interaction between fertilizer rate and varieties for vine length, TIS87/0087 and UMUSP01 gave the highest and lowest length of vines respectively at all the fertilizer rates. At four weeks $300 \mathrm{~kg} / \mathrm{ha}$ gave the highest value of vine length. TIS87/0087 remains consistently higher at various levels of fertilizer applies

TABLE 2: Effect of different rates of NPK 15:15:15 fertilizer on the length of vines of three varieties of sweet potato

\section{NPK FERTILIZER}

\begin{tabular}{|c|c|c|c|c|c|}
\hline & NPK 0 KG & NPK 200 KG & NPK 300 KG & NPK $400 \mathrm{KG}$ & Mean \\
\hline VARIETY & \multicolumn{5}{|c|}{ LENGTH OF VINES 2 WAP } \\
\hline TIS 87/0087 & 7.61 & 6.35 & 7.28 & 8.1 & 7.34 \\
\hline UMUSPO3 & 5.32 & 6.37 & 7.42 & 8.21 & 6.83 \\
\hline UMUSPO1 & 4.86 & 5.68 & 7.06 & 6.89 & 6.08 \\
\hline MEAN & 5.87 & 6.13 & 7.25 & 7.74 & \\
\hline VARIETY & \multicolumn{5}{|c|}{ LENGTH OF VINES 4 WAP } \\
\hline TIS 87/0087 & 16.21 & 25.96 & 25.08 & 22.62 & 22.47 \\
\hline UMUSPO3 & 10.37 & 16.68 & 17.75 & 15.94 & 15.19 \\
\hline UMUSPO1 & 14.69 & 14.00 & 15.44 & 13.56 & 14.42 \\
\hline \multirow[t]{2}{*}{ MEAN } & 13.75 & 18.88 & 19.42 & 17.37 & \\
\hline & & & & LOV 2 WAP & LOV 4 WAP \\
\hline LSD (0.05) for & ato variety r & & & N.S & 4.04 \\
\hline LSD $(0.05) \mathrm{NP}$ & Fertilizer $n$ & & & N.S & N.S \\
\hline $\operatorname{LSD}(0.05)$ for & toes variet & 15:15:15: Ferti & eans & N.S & N.S \\
\hline
\end{tabular}

The variety that gave the highest number of established plant is Umuspo 1. TIS 87/0087 had the least establishment. All the varieties show significant $(p<0.05)$ plant establishment.
- Plant establishment

TABLE 3 revealed the effect NPK 15:15:15 fertilizer on the number of plant establishment of 3 varieties of sweet potato,

TABLE 3: Effect of different rates of NPK15:15:15 fertilizer on the number of plants established

\section{NPK FERTILIZER}

\begin{tabular}{lccccc}
\hline & NPK 0 KG & NPK 200 KG & NPK 300 KG & NPK 400 KG & Mean \\
\hline VARIETY & & & & & \\
TIS 87/0087 & 2.00 & 4.75 & 3.75 & 3.25 & 3.44 \\
UMUSP03 & 4.50 & 4.25 & 5.00 & 3.50 & 3.31 \\
UMUSP01 & 7.75 & 7.50 & 7.75 & 5.00 & 7.75 \\
MEAN & $\mathbf{3 . 7 5}$ & $\mathbf{4 . 5 0}$ & $\mathbf{4 . 5 0}$ & & \\
\hline
\end{tabular}

LSD (0.05) for sweet potato variety means LSD (0.05) NPK 15:15:15 Fertilizer means LSD (0.05) for sweet potatoes variety X NPK 15:15:15: Fertilizer means
Number of Plants established 0.86

N.S

N.S 


\section{- Yield Parameter}

The effect of different levels of NPK fertilizer on tuber length of different varieties of sweet potato is presented in TABLE 4 below.
Generally, TIS87/0087 recorded the longest tuber at various fertilizer rates, while Umuspo 3 recorded shortest tuber.

TABLE 4: Effect of different levels of NPK 15:15:15 fertilizer on the tuber length of different varieties of sweet potato.

FERTILIZER RATE (Kg/ha)

\begin{tabular}{lccccc}
\hline & NPK 0 KG & NPK 200 KG & NPK 300 KG & NPK 400 KG & Mean \\
\hline $\begin{array}{l}\text { SWEET POTATO VARIETY } \\
\text { TIS 87 /0087 }\end{array}$ & 16.86 & 18.93 & 15.87 & 21.32 & 18.25 \\
UMUSP03 & 11.00 & 11.01 & 10.40 & 16.86 & 13.40 \\
UMUSP01 & 14.34 & 13.44 & 18.62 & 15.61 & 15.50 \\
MEAN & $\mathbf{1 4 . 0 7}$ & $\mathbf{1 4 . 7 3}$ & $\mathbf{1 4 . 9 6}$ & $\mathbf{1 7 . 9 3}$ & \\
\hline
\end{tabular}

LSD (0.05) for sweet potato variety means

Tuber Length

$$
5.62
$$

1.51

N.S
Fertilizer rates and variety showed significant difference for both yield per plant and yield per hectare. There were no interaction between variety and fertilizer for both parameters.
TABLE 5 below showed the effect of different levels of NPK 15:15:15 fertilizer on the tuber yield of different varieties of sweet potato. TIS/87/0087 had highest plant yield per plant and highest yield per hectare while Umuspo 3 recoded lowest yield per plant and lowest yield per hectare.

TABLE 5: Effect of different levels of NPK 15:15:15 fertilizer on the tuber yield of different varieties of sweet potato

FERTILIZER RATE (Kg/ha)

\begin{tabular}{|c|c|c|c|c|c|}
\hline $\begin{array}{l}\text { SWEET POTATO } \\
\text { VARIETY }\end{array}$ & NPK 0 KG & NPK $200 \mathrm{KG}$ & NPK 300 KG & NPK $400 \mathrm{KG}$ & Mean \\
\hline \multicolumn{6}{|l|}{ Kg/plant } \\
\hline TIS 87/0087 & 0.82 & 1.36 & 1.54 & 1.36 & 1.27 \\
\hline UMUSPO3 & 0.68 & 0.81 & 0.50 & 0.68 & 0.67 \\
\hline UMUSPO1 & 0.45 & 1.11 & 0.66 & 0.78 & 0.75 \\
\hline MEAN & 0.65 & 1.09 & 0.90 & 0.94 & \\
\hline \multicolumn{6}{|l|}{ Tones/ha } \\
\hline TIS 87/0087 & 1.03 & 1.86 & 1.93 & 1.53 & 1.59 \\
\hline UMUSPO3 & 0.57 & 1.15 & 0.63 & 0.05 & 0.88 \\
\hline UMUSPO1 & 0.56 & 1.38 & 0.82 & 0.98 & 1.94 \\
\hline \multirow[t]{2}{*}{ MEAN } & 0.82 & 1.46 & 1.13 & 1.12 & \\
\hline & & & & $\mathrm{Kg} /$ plant & t/ha \\
\hline \multicolumn{4}{|c|}{ LSD $(0.05)$ for sweet potato variety means } & 7.97 & 7.14 \\
\hline \multicolumn{4}{|c|}{ LSD (0.05) NPK 15:15:15 Fertilizer means } & 1.87 & 2.38 \\
\hline \multicolumn{4}{|c|}{ LSD (0.05) for sweet potatoes variety X NPK 15:15:15: Fertilizer means } & N.S & N.S \\
\hline
\end{tabular}

\section{DISCUSSION}

The experiment revealed that Umuspo1had the highest number of leaves, at $300 \mathrm{~kg} / \mathrm{ha}$ while Tis87/0087 showed longest vine length at 4 weeks after planting. This result showed that the growth performance of this varieties differed. The trend observed was that as the fertilizer rate increases the vine length increases. This shows that fertilizer application improves the growth of sweet potato. This result agrees with the findings of Tesfayeet al., 2003 which states that the application of maximum fertilizer helps in foliage development for better fresh foliage production for livestock feed.Generally, for the above discussed growth parameters, varieties and fertilizer rates did not show interaction.TIS87/0087, an improved variety recorded the highest number tubers when compared to other cultivars. This resultreveals that TIS87/0087had the highest tuber size, this can be of great interest for international market and for cross breeding purposes (Okoli, 2020).

Variety and fertilizer rates differed on their effects on weight of marketable and unmarketable tubers since they were both significant for both parameters, fertilizer rates were significant for almost all yield attributes. The experiment revealed that without fertilizer application, the 
growth of sweet potatoes will be very poor and so will the yield, with the application of NPK fertilizer $(15: 15: 15)$ at $300 \mathrm{~kg} / \mathrm{ha}$ the yields were improved and further increase improve vegetative growth at the expense of tuber yield which was not economical to operate.

\section{CONCLUSION}

The lack of significant response exhibited by the sweet potato varieties can be attributed to the state and inherent conditions of cultivar itself. Sweet potato has colonized marginal soils because it readily produces adventitious roots and trailing vines. It shows good tolerance to aluminum rich phosphorous poor acid soils. This means that crop was able to utilize the number of nutrients in soil for growth and development. The result from present study reveals that TIS/87/0087 (an improved variety of sweet potato) canbe used for production for higher yield at the fertilizer rate of $300 \mathrm{~kg} / \mathrm{ha}$ NPK 15:15:15 at Igbariam, Anambra State, Nigeria.

\section{REFERENCES}

[1] FAO (2001).World Market for Organic Fruit and Vegetables Opportunity for Developing Countries in Production and Export of organic Horticulture products. Technical Trade Centre, Technical CenterFor Agricultural and Rural Cooperation, FAO Rome.

[2] FAOSTAT (2010). Food and Agricultural Organisation Statistical Data base; Agricultural items (assessed 22 January 2012) http://faostat.faso.org
[3] Lenne, J.M (1991). Disease and Pest of Sweet Potato; South East Asia the Pacific and East Africa Natural Resources Institutes Bulletin 46(7):116.

[4] Obi, I.U (2002).Statistical methods of detecting differences between treatment means and research methodology issues in labouratory and field experiments. $2^{\text {nd }}$ ed. Published by AP Express Publishers limited Nsukka Nigeria.

[5] Okoli, E.E. (2020). Consumption and Acceptability Pattern of 21 Evaluated Maize Hybrids for Fresh Maize Production in South-Eastern Nigeria. CARI JOURNALS, Journal of Agricultural Policy, Vol.3, Issue No.2, pp $45-52$.

[6] Okoli, E.E. and Okoronkwo C.M. (2020). Heritability and combining ability estimates among seven varieties of maize in Southeastern Nigeria. International Journal of Science, Environment and Technology, Vol. 9, No 2, 98- 107.

[7] Tesfaye M, Temple SJ, Allan DL, Vance CP \&Samac DA (2001). Overexpression of malate dehydrogenase in transgenic alfalfa enhances organic acid synthesis and confers tolerance to aluminum Plant Physiol. 127: 1836-1844 